\title{
DOBROĆ UWALNIAJĄCA Z "GRY W WARTOŚCI". O DEKONSTRUKCJI MYŚLENIA AKSJOLOGICZNEGO
}

Pierwotnie wartość, greckie à̉ia (aksia), oznaczała „coś poddanego ocenie", ale także: cenę, godność, zasługę ${ }^{1}$. Gdy filozofowie, w tym i fenomenolodzy, mówią o wartościach, często $\mathrm{w}$ analizach tych kryje się postrzeganie wartości jako czegoś, co da się zmierzyć, czegoś, w czym pobrzmiewa logika oceny i ceny. Wartości są $\mathrm{w}$ tej perspektywie korelatami potrzeb, tych naturalnych, związanych z biopsychiczną homeostazą organizmu i otoczenia, ale też tych sztucznych, będących pożądaniami wygenerowanymi przez lęk o siebie. Heideggerowski program myślenia przeciw wartościom był próbą zmierzenia się z takim przedmiotowym traktowaniem wartości oraz odpowiedzią na nieistotność filozoficznego mówienia o nich. Skutkiem zaproponowanej przez Heideggera dekonstrukcji myślenia aksjologicznego było odnowienie filozoficznej refleksji nad fenomenem wartości. A ponieważ, według niego, wartość została pozbawiona godności (paradoksalnie, gdyż greckie aksia oznaczało także ten typ godności, który pochodzi z uznania), wzywał on do myślenia przeciwko wartościom, a zatem przeciw uprzedmiotawiającym konstruktom, poprzez które wartościowanie „staje 
się wyłącznie przedmiotem ludzkiej oceny”2 oraz "największym bluźnierstwem"3, jakie można popełnić przeciwko fenomenom źródłowym 4 .

Współcześnie, gdy filozofowie używają kategorii wartości, zazwyczaj mają na myśli coś więcej niż logika oceniania czy mierzenia wartości. A jednak techniczny, akademicki język i prymat ustawienia wszystkiego wedle miar i ściśle określonych hierarchii przywołuje na myśl granie w grę, której zasady każdy z nas zna i wcześniej lub później musi zacząć w nią grać.

Określenie "gra w wartości" ujawnia akcentowanie tylko przedmiotowego wymiaru wartości; to z jednej strony traktowanie wartości jako czegoś rozporządzalnego, co poddaje się człowiekowi („grać w coś" znaczy opanować to), z drugiej zaś wartości są tylko grą, to jest czymś, co ma ściśle określone reguły, stworzone przez człowieka, i co poddaje się jego modyfikacjom. "Gra w wartości" polega na konstruowaniu i upraszczaniu fenomenu wartości, szczególnie zaś fenomenu dobra, który będąc schematyczny, funkcjonuje jako pewnego rodzaju wyabstrahowana norma, pozbawiona ugruntowania w doświadczeniu Dobroci.

Gra jest wtedy, gdy grający nie widzą poza nią rzeczywistości, gdy przyjmują zasadę, iż to, co poza grą, nie istnieje czy nie jest ważne. A zatem grać można tylko, gdy w pełni przyjmie się reguły gry, negując tym samym - czy relatywizując do reguł gry - istnienie wszystkiego spoza niej. Gra jest przeto zawsze systemem zamkniętym. Dodatkowo, gra - inaczej niż zabawa - ma zawsze określony cel, którym jest wygrana ${ }^{5}$, podczas gdy w zabawie jak w tańcu - chodzi raczej o sam akt zabawy, który nie ma ściśle określonych reguł, warunków wygranej/przegranej, a nawet wyznaczonego końca. Dlatego też gra abstrahuje od rzeczywistości, tworząc nową przestrzeń, uproszczoną i poddaną regułom, gdzie warunek wygranej - tego, kto będzie lepszy stanowi istotę gry. Ponadto, gra jest zawsze oparta o rywalizację, o swoistą walkę - w grze można być lepszym lub gorszym, posługiwać się "dobrymi" bądź „złymi” strategiami, by wygrać z przeciwnikiem. Gra może, choć nie musi, odnosić się do obiektywnych potrzeb podmiotu grającego, ale może też konstruować świat potrzeb i sztucznych uzależnień od nich, podczas gdy zabawa jest zawsze bezinteresowna: „znajduje się poza procesem bezpośredniego zaspokajania konieczności i żądz, a nawet proces ów przerywa"6.

${ }^{2}$ M. Heidegger, List o „humanizmie”, tłum. J. Tischner, [w:] idem, Budować, mieszkać, myśleć. Eseje wybrane, Warszawa 1977, s. 111.

${ }^{3}$ Ibidem.

4 ,[...] jakie można pomyśleć przeciwko byciu"; ibidem.

${ }^{5}$ J. Tischner, Spór o istnienie człowieka, Kraków 1998, s. 105.

${ }^{6}$ J. Huizinga, Homo ludens. Zabawa jako źródło kultury, tłum. M. Kurecka, W. Wirpsza, Warszawa 2007, s. 22. 
Choć Johan Huizinga w swoim Homo ludens nie odróżnia gry od zabawy, to zauważa jedną arcyważną kwestię: osoba, która niszczy grę („psuj gry”), jest gorsza od fałszywego gracza7, gdyż poprzez sprzeciwienie się regułom sprzeniewierza się całej grze - niszczy ją, podczas gdy oszust akceptuje zasady po to, by móc je obejść. „Psuj gry” naraża całość gry, w tym jej niezwykle chronioną powagę, oszust jedynie wynik, dzięki czemu gra może toczyć się dalej. Stąd Heidegger często jest określany jako enfant terrible aksjologii czy nawet heretyk fenomenologii: „psuj gry”, który podważył jej powagę i zasadność.

W „grze w wartości" rzeczywistość jest zawsze ustanawiana według dualistycznego światoobrazu: złu przeciwstawiane jest dobro, co sugeruje tym samym, że możliwe jest ich przeciwstawienie, że da się je jakoś zmierzyć, tak jakby dobro i zło, korzyść czy strata, miały ze sobą coś wspólnego, jakby pochodziły z tej samej płaszczyzny, jakby dobro przynależało do poziomu aksjologicznego, nie zaś go warunkowało. Właśnie przeciw takiemu zontologizowaniu wartości występuje Heidegger, a później Emmanuel Lévinas.

Współczesna fenomenologia wartości przypomina czasem "grę w wartości", a jej założenia są trudne do podważenia, gdyż wypływają z autorytetu fenomenologii Husserlowskiej, co samo w sobie ma być uzasadnieniem ich prawomocności. „Gra aksjologiczna” jest związana z wprowadzoną przez Husserla koncepcją podmiotu i miejsca języka w fenomenologii, gdzie znaczenie zawsze jest generowane przez podmiot, a język jest tylko narzędziem służącym do opisu, nigdy zaś tym, co mogłoby przekraczać sferę czystego podmiotu. Podmiot zatem jest już zawsze ustanowiony, a jego mowa nie wpływa na jego konstytucję 8 . Wykluczenie pozapodmiotowego znaczenia pokutuje $\mathrm{w}$ analizach aksjologicznych, które tworzone są tylko na miarę podmiotu tetycznego, podmiotu ukształtowanego (gesetzt) i kształtującego/ustanawiającego $(\operatorname{setz} t)^{9}$, co prowadzi do prób możliwie "czystego", to jest obiektywistycznego i jednoznacznego opisywania wartości, w którym ich uprzedmiotowienie jest koniecznym, a nawet pożądanym skutkiem. Można powiedzieć, że aksjologia inspirowana fenomenologią Husserlowską jest tylko na miarę przyjmowanych reguł gry - na próżno szukać w niej innej rzeczywistości, niż gra zakłada.

Choć w fenomenologii Husserla funkcja języka sprowadza się tylko do bycia narzędziem, to podejście to zmienia się $\mathrm{w}$ późnej fenomenologii,

7 Ibidem.

8 M.P. Markowski, Przygoda ciała i znaków. Wprowadzenie do pism Julii Kristevej, [w:] J. Kristeva, Czarne słońce. Depresja i melancholia, tłum. M.P. Markowski, R. Ryziński, Kraków 2007, s. VII.

${ }^{9}$ Ibidem. 
szczególnie w wydaniu hermeneutycznym ${ }^{10}$. A zatem, wbrew Husserlowi, hermeneuci powiedzą: „To nieprawda [...], że świat pojawia się (dla nas i dla wszystkich możliwych podmiotów), zanim zaczniemy mówić", gdyż język jest „strukturą samego zjawiania się"11. W ten sposób język przestaje być traktowany jak kolejna z rzeczy tego świata, a okazuje się jego horyzontem. Dzięki temu Heideggerowskie myślenie przeciw wartościom nabiera nowego znaczenia, zgodnie z którym "język mówi” (die Sprache spricht), a „człowiek mówi tylko wtedy, gdy odpowiada językowi"12. Charakterystyczną cechą tego sposobu myślenia o języku jest jego otwartość na rzeczywistość poza/przedpodmiotową, gdzie podmiot się staje („istoczy”, mówiąc językiem Heideggera), a wieloznaczność języka oraz filozofii przestaje być wadą. Zarzucenie kontrolowalności opisu to zaprzestanie prób kontrolowania sfery zjawiania się - już nie świadomość, a język, wraz ze swoją wieloznacznością oraz koniecznością interpretacji, staje się macierzą filozofii, a przez to i aksjologii.

Nie oznacza to jednak, iż analizy aksjologiczne mają mieć tylko językowy charakter. Chodzi tu raczej o zwrócenie uwagi na relację języka/mowy i doświadczenia oraz tego, iż każde doświadczenie wydarza się już w horyzoncie języka/mowy (a przez to jest zapośredniczone interpretacją), nawet jeśli jest to tylko "język" pierwotny (jak u niemowlęcia). Interpretacja ta, nawet na gruncie nauki, ma być interpretacją żywą, to jest snutą przez żywy podmiot, który się staje i który interpretuje siebie i świat całym sobą: doświadczenie jest już interpretacją, a ta sposobem bycia (doświadczania). Szczególnie w kontekście doświadczenia aksjologicznego interpretacja jako sposób bycia odgrywa kluczową rolę: opisywanie wartości na sposób neutralny byłoby właśnie, mówiąc za Heideggerem, poniżeniem samej istoty wartości: bluźnierstwem. Co jednak z nauką? Jak mówić o wartościach tak, by analizy te były intersubiektywnie komunikowalne? Konieczne jest tu wprowadzenie podziału metodologicznego, który z jednej strony wskaże na samą istotę wartości - „wartościowość wartości” - oraz na wagę inicjacji w myślenie tej źródłowej płaszczyzny, którą za Lévinasem nazywam Dobrem/Dobrociąi13, a z drugiej strony na dyskurs o wartościach (między in-

\footnotetext{
${ }^{10}$ Niemałą rolę odegrała tu również psychoanaliza.

${ }^{11}$ K. Michalski, Logika i czas. Próba analizy Husserlowskiej teorii sensu, Warszawa 1988, s. 167.

${ }^{12}$ M. Heidegger, Jezyk, [w:] idem, W drodze do jezzyka, tłum. J. Mizera, Warszawa 2007, s. 26.

${ }^{13} \mathrm{Za}$ Antonim Jarnuszkiewiczem SJ twierdzę, że Lévinasowskie le Bien, pisane wielką literą - które zazwyczaj przekładane jest jako „Dobro” - lepiej jest w tym kontekście tłumaczyć jako „Dobroć”, i że Lévinas używa takiego zapisu zawsze wtedy, gdy chce podkreślić metaaksjologiczność Dobra/Dobroci. Tłumaczenie le Bien jako „Dobroci” od razu akcentuje jego osobowy charakter, a tym samym odróżnia Dobroć od wielości dóbr realizowanych na płaszczyźnie ontologicznej (poziom potrzeb), przede wszystkim zaś podkreśla ponadbytowy cha-
} 
nymi o dobru), ich analizowalność i w ogóle możliwość tworzenia nauki o wartościach - aksjologii. Płaszczyzny te nie są i nie mogą być od siebie odseparowane; gdy się tak jednak dzieje, aksjologia staje się nieludzka bezosobowa, bo przecież i w państwach totalitarnych włada aksjologia, a mówiąc ściślej, nie ma $\mathrm{w}$ nich nic poza aksjologią - ułożeniem wartości według nieludzkiej miary (totalitaryzm to niezaangażowana i w pełni kontrolowalna "gra w wartości").

Powiązanie języka z Dobrocią Lévinas eksplikuje w Całości i nieskończoności, gdzie zaznacza, iż nie istnieje żadne wcześniejsze, odrębne Ja, które dopiero miałoby wychodzić poza siebie ${ }^{14}$. Ja wydarza się wraz z tym wychodzeniem na zewnątrz po to, by wyrażać siebie: $w$ geście, $w$ odpowiedzi w Transcendencji. Język to Dobroć - mówi Lévinas - i nie ma w nim miejsca dla "ontologii oderwanej podmiotowości” czy "ontologii bezosobowego rozumu spełniającego się $\mathrm{w}$ historii"15. Dobroć ujawnia się $\mathrm{w}$ mowie ${ }^{16}$, a mowa zamieszkuje w Dobroci, zaś w nich dwóch Ja zawsze pozostaje sobą: o-sobą. Język i mowę u Lévinasa należałoby tu przeciwstawić Heideggerowskiej "gadaninie" (Gerede): temu, co nie mówi, a zagłusza, temu, co można by nazwać bezistociem wyrzucanych z siebie dźwięków i gestów, które zamiast wyrażać - maskują. Dopiero z mowy (czy języka), które są Dobrocią, a które polegają na "objawianiu się Innego", wyłania się język jako system znaków ${ }^{17}$. Pierwotny jest tu sens, będący ethosem: mowa znajduje się przed podmiotowo-przedmiotowym stosunkiem do Innego, jest źródłową (etycz-

rakter Dobra/Dobroci. Por. A. Jarnuszkiewicz SJ, Od systemu do etyki. Krytyka rozumu dialogicznego, Kraków 2012, s. 10. Interpretację tę uprawomocnia sam Lévinas, który w Inaczej niż być lub ponad istota (tłum. P. Mrówczyński, Warszawa 2000) mówi wprost o "Dobroci Dobra": „Uprzedniość odpowiedzialności względem wolności oznaczałaby Dobroć Dobra [la Bonté du Bien]: konieczność, aby Dobro [le Bien] mnie wybrało, zanim ja będę w stanie je wybrać, to znaczy przyjąć jego wybór. Na tym polega moja pra-źródłowa podatność” (ibidem, s. 208). „To, że Dobro [le Bien] w swojej dobroci [bonté] odchyla pragnienie, jakie we mnie budzi, i kieruje je ku odpowiedzialności za bliźniego, pozwala zachować różnice w nie-indyferencji Dobra [Bien], które wybiera mnie, zanim ja je przyjmę" (s. 209). „Dobro [le Bien], jako Nieskończoność, nie ma swojego innego, nie dlatego, że jest całością, ale dlatego, że jest Dobrem [Bien] i nic nie wymyka się jego dobroci [bonté]” (s. 24-25, przypis 8). „Dobroć [la bonté], chociaż pojawia się na skraju istoty, jest inna niż bycie - niczego już nie rozlicza. Nie jest jak negatywność, która zachowuje w swoich dziejach to, co neguje. [...] Wyjątkowy, nad-zwyczajny i transcendujący charakter dobroci [la bonté] polega właśnie na tym zrywaniu z byciem i jego historią. Sprowadzać dobro [le bien] do bycia - do jego rachunków i historii - to przekreślać dobroć [la bonté]. [...] Dobroć [la bonté] nadaje podmiotowości jej nieredukowalne znaczenie" (s. 36-37).

${ }^{14}$ E. Lévinas, Całość i nieskończoność. Esej o zewnętrzności, tłum. M. Kowalska, Warszawa 2012, s. 368-369.

${ }^{15}$ Ibidem, s. 368.

16 Ibidem, s. 369.

17 Por. ibidem, s. 72. 
ną) relacją z Innym ${ }^{18}$. Język/mowa (czy właściwie rozmowa: discours) mają tu przede wszystkim wymiar czasownikowy, są przed tematyzacją. Lévinas rozszerza ten wątek w Inaczej niż być lub ponad istota za pomocą podziału na powiedziane (le dit) i mówione (le dire), które w języku polskim, by wybrzmiał tu aspekt czasownikowy ${ }^{19}$, lepiej jest oddać jako mówić. Powiedziane rodzi się z mówić, tak jak źródłem aksjologii jest Dobroć, która uwalnia z gry i totalitarnej tematyzacji (i ontologizacji) wartości.

Dlatego też, w przeciwieństwie do "gry w wartości", Dobroć jest tym, co otwiera, jest "pragnieniem dobra, wykraczającym poza byt” 20 , a zatem wykraczającym poza reguły gry. Tym samym okazuje się, że Dobroć (le Bien) pochodzi z zupełnie z innego porządku niż "dobro" i „zło” (sytuuje się ponad czy „poza dobrem i złem” lub istnieje „inaczej niż dobro i zło”), gdyż przychodzi spoza gry, a jej zadaniem jest nie tyle zniszczyć grę, co z niej uwolnić; zamienić grę - namiastkę bliskości - w taniec, perichoretyczną bliskość. Dlatego też dla podkreślenia absolutnego (to jest uwalniającego, od łac. absolvere) charakteru Dobroci nazywam ją kategorią meta-aksjologiczną (meta-fizyczną), to jest pochodzącą spoza logiki oceny i merkantylnego spojrzenia. Podobne intuicje można odnaleźć choćby u Józefa Tischnera, w jego próbach różnicowania aksjologii i agatologii, czy u Maxa Schelera $\mathrm{w}$ jego ordo amoris, będącym tym, co ożywia wartości i wyrywa je ze sfery przedmiotowej, a co jest korzeniem wszelkiej aksjologii (wartością nadającą wartość wszelkim wartościom).

Jednak nie chodzi tu o to, by w ogóle przestać uprawiać aksjologię, a raczej o konieczność (nie tylko ze względów metodologicznych) oddzielenia aksjologii od tego, co ją w ogóle umożliwia: od wymiaru Dobroci, będącego arché wartości. Jednak idąc za Lévinasem, wymiar ten - dla podkreślenia jego absolutnej źródłowości i dynamiczności - można nazwać jeszcze dosadniej jako an-arché21. Chodzi tym samym o znalezienie metaphisicum wartości. W tym miejscu konieczne jest wyeksplikowanie rozróżnienia na feno-

18 Por. ibidem, s. 244.

19 "Stąd też język nie sprowadza się do systemu znaków, które są duplikatem bytów i relacji - koncepcja taka byłaby nie do odrzucenia, gdyby słowo było Nazwą. Język jest raczej naroślą na czasowniku. I już jako czasownik oddaje życie zmysłowe - temporalizację i istotę bycia. Doznane wrażenie - bycie i czas - słyszalne jest już w czasowniku"; E. Lévinas, Inaczej niż być lub ponad istota, op. cit., s. 62.

${ }^{20}$ E. Lévinas, O Bogu, który nawiedza myśl, tłum. M. Kowalska, Kraków 2008, s. 142.

${ }^{21}$ Zob. M. Małecka, Od arché-(o)logii do an-archii: meandry źródtowości, [w:] Oblicza filozofii. Profesorowi Wtadystawowi Stróżewskiemu w darze w 80. rocznice urodzin, red. M. Borys, J. Sadowski, Kraków 2013. 
men dobra i Enigmę Dobroci, rozróżnienia, którego inspiracją jest myśl Lévinasa, kontynuowana przez Antoniego Jarnuszkiewicza SJ ${ }^{22}$.

O dobru można mówić z dwóch perspektyw: z poziomu aksjologicznego, gdzie dobro jawi się jako fenomen dobra, coś, co się pokazuje, dzięki czemu jest możliwe do analizy, a nawet pewnego rodzaju operacjonalizacji; oraz z poziomu metaaksjologicznego, gdzie Dobro przestaje być traktowane jako wartość na równi z innymi i okazuje się nie fenomenem, a raczej enigmą - Enigmą Dobroci. Podział na fenomen i enigmę po części mogą rozjaśnić Heideggerowskie analizy przejawu i fenomenu, zawarte $\mathrm{w}$ paragrafie siódmym Bycia i czasu. Greckie phainomenon (paivójevov) ${ }^{23}$ oznacza to, co się ukazuje i jest związane $\mathrm{z}$ widzialnością poprzez swoje połączenie $\mathrm{z}$ grec-

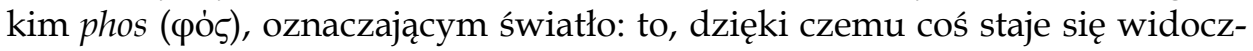
ne. Stąd fenomen to coś, "co-się-samo-w-sobie-ukazuje”, gdyż zawiera już $\mathrm{w}$ sobie światło. Ale $\mathrm{w}$ greckim słowie phainomenon tkwi też inne znaczenie fenomenu: jako pozoru, tego, co tylko „wygląda tak, jak...”, co pokazuje się jako coś, czym nie jest. To drugie znaczenie Heidegger określa jako „prywatną modyfikację fenomenu" i odróżnia od pierwszego i źródłowego rozumienia fenomenu jako ukazywania się. Z kolei przejaw (Erscheinung) to anonsowanie się tego, co się nie ukazuje (skrywa), poprzez to, co się pokazuje: przejaw to oznajmianie się nieukazywalnego. Przejaw jako przeświecanie (scheinen) jest zaraz skrywaniem się i ukazywaniem, ale ukazywaniem tylko tego, co może się pokazać24. Dynamikę tych analiz dobrze oddaje przykład symptomu w chorobie: symptom, będąc tym, co widoczne, anonsuje chorobę, która zawsze się skrywa. Dostęp do choroby jest możliwy tylko poprzez pokazanie się jej symptomów, które przeświecając - zapowiadają ją i po części ujawniają, choć sama choroba nigdy się nie ujawnia w pełni. Podobnie jest $\mathrm{z}$ fenomenem i enigmą: enigma jest fenomenem $\mathrm{w}$ sensie źródłowym tym, co się samo w sobie ukazuje. Na gruncie aksjologii wartości są przejawami Dobroci, każda wartość ma w sobie źródłowy wymiar Dobroci, jeśli jednak w jakiś sposób została go w analizie pozbawiona, staje się zaledwie fenomenem $\mathrm{w}$ sensie pozoru (prywatyzacją fenomenu, podatną na przekształcenia), pseudo-wartością, która utraciła swoje źródłowe zagnieżdże-

${ }^{22} \mathrm{~W}$ kwestii rozróżnienia na fenomen i enigmę zob. A. Jarnuszkiewicz SJ, op. cit., s. 62, 70-71. Natomiast intuicja, by rozróżnić fenomenem dobra i enigmę Dobroci, pojawiła się podczas rozmów autorki z Antonim Jarnuszkiewiczem SJ.

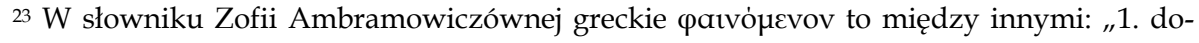
bywać na jaw, pokazać, ukazać; 2. świecić, wyjść na jaw; 3. okazać się, wydać się jakimś, 4. ukazywać się zmysłom, być oczywistym; 5. wydawać się (słusznym, właściwym)"; Słownik grecko-polski, t. IV, red. Z. Abramowiczówna, Warszawa 1965.

${ }^{24}$ M. Heidegger, Bycie i czas, tłum. B. Baran, Warszawa 2005, s. 36-40. 
nie. Przejaw, jak powiada Heidegger, jest „kontekstem odniesień w samym bycie", nie istnieje bez fenomenu, choć fenomen może istnieć bez przeja$w^{25}$. Wartości nie byłoby zatem bez Dobroci, choć możliwe jest teoretyczne opisywanie ich bez tego podstawowego poziomu, który nadaje im dynamikę i żywość oraz sprawia, że są właśnie wartościami, a nie tworami teoretycznymi. By jednak nie zaciemniać analiz i nie odbierać wartościom statutu fenomenu - $\mathrm{w}$ rozumieniu, jakie jest powszechnie używane na gruncie fenomenologii ${ }^{26}$ - określam Dobroć jako enigmę, zaś dobro (aksjologiczne) jako fenomen. Dobroć jest sui generis przedmiotem „pragnienia (désir) metafizycznego", a dobro przedmiotem potrzeb czy pożądań. Rozróżnienie na potrzeby i pragnienie pochodzi od samego Lévinasa ${ }^{27}$, który poziom metafizyczny opisuje poprzez niespełnialność pragnienia absolutnie Innego, pragnienia, które nie mając kresu, jest niemożliwe do zaspokojenia ${ }^{28}$. Broni ono przed chęcią zagarnięcia Inności i sprowadzenia jej do Toż-samego. Dlatego też pragnienie metafizyczne jest Dobrocią - Enigmą Dobroci, uwalniającą z myślenia napędzanego lękiem o siebie i przymusem zrealizowania jak największej ilości „dóbr”. Natomiast poziom ontologiczny (i aksjologiczny) jest już uwikłany w logikę potrzeb (biologicznych, społecznych, moralnych, religijnych, estetycznych itd.), które o ile pozostaną na swoim miejscu - to jest będą realizowane $\mathrm{w}$ obrębie ontologii i aksjologii, bez roszczenia sobie pretensji do bycia metaphysicum rzeczywistości - spełniają swoją funkcję, między innymi dostarczając środków koniecznych do biologicznego życia,

25 „Fenomeny zatem nigdy nie są przejawami, choć każdy przejaw jest zdany na fenomeny"; ibidem, s. 38 .

${ }^{26}$ Nie bez powodu szczegółowe rozstrzygnięcia Heideggera z paragrafu siódmego Bycia i czasu dotyczące fenomenu i przejawu nie zostały prawie w ogóle przyjęte na gruncie fenomenologii. Sądzę, iż zaważyła tu ekonomia myśli, i choć analizy Heideggera uważam za nadzwyczaj trafne, stosowanie uproszczonego rozumienia fenomenu wydaje się lepszym rozwiązaniem.

27 „Stwierdziliśmy, że metafizyka jest Pragnieniem. Pragnienie (przeciwstawne potrzebie) opisaliśmy jako «miarę» Nieskończoności, której nie zatrzymuje żaden kres, żadne spełnienie. [...] Twierdzenie, że metafizyka jest Pragnieniem, znaczy, iż wytwarzanie bytu, pragnienie, które rodzi Pragnienie, jest dobrocią [bonté] wyższą nad szczęście i że byt urzeczywistnia się, kiedy jesteśmy dla Innego" (E. Lévinas, Całość i nieskończoność. Esej o zewnętrzności, op. cit., s. 367). „Prawdziwym Pragnieniem jest to, którego Upragnione nie wypełnia, lecz pogłębia. Jest dobrocią. Nie odnosi sie do jakiejś utraconej ojczyzny czy pełni, nie jest tęsknotą za powrotem - nie jest nostalgią. Jest brakiem w bycie, który jest kompletnie i któremu nic nie brakuje" (idem, Odkrywając egzystencję z Husserlem i Heideggerem, tłum. E. Sowa, Warszawa 2008, s. 184). „Potrzeba jest wyrazem pustki i braku w potrzebującym, wyrazem jego zależności od zewnętrznego świata, jego niewystarczalności. [...] Dobro [le Bien] jest Dobrem [Bien] w sobie, a nie w stosunku do potrzeby, która odczuwałaby jego brak. Z perspektywy potrzeb, Dobro [le Bien] jest luksusem. Właśnie dlatego leży ponad bytem” (idem, Całość i nieskończoność. Esej o zewnętrzności, op. cit., s. 111).

28 Ibidem, s. 29. 
zapewniając bezpieczeństwo emocjonalne, realizując wartości estetyczne itp. Gdy jednak zostaną wzięte za istotę rzeczywistości i miarę człowieka - to jest gdy zaczną podszywać się pod pragnienie metafizyczne, wprowadzając przymus ich spełniania czy realizacji - stają się pożądaniami, z których błędnego koła nie sposób się uwolnić bez przebudzenia i odkrycia na nowo pragnienia metafizycznego. Kluczowe jest jednak to, że niespełnialność pragnienia metafizycznego jest właśnie enigmatyczna - niezrozumiała dla umysłu rachującego, domagającego się poznawczego zaspokojenia. Jest porządkiem osobowym - Dobrocią, która wykracza poza to, co możliwe do kontroli, i która każdorazowo niszczy grę.

Ponieważ enigma to "ukazywanie się bez ukazywania się"29, to ze względu na jej „nieuchwytywalność w pojęcia”30, można ją przeciwstawić fenomenowi. $W$ tym też sensie enigma łączyłaby dwa Heideggerowskie terminy: przejaw i fenomen; enigma, z jednej strony, się skrywa, z drugiej zaś - ukazuje się, choć w sposób niemożliwy do uprzedmiotowienia. Dlatego też enigma nie jest ani sekretem, ani tajemnicą. Sekret jest czymś, co można wypowiedzieć i wyjawić komuś, czymś, co - gdy zostanie w całości ujawnione - przestaje być sekretem; tajemnica zaś jest tym, czego nie da sie wypowiedzieć, a tym samym czymś, co nigdy nie zostanie odsłonięte - to, co tajemnicze, zawsze się skrywa i pozostaje $w$ mroku ${ }^{31}$. Inaczej enigma: będąc na pograniczu skrywania i ujawniania się (jak Heideggerowska aletheia), chroni to, co istotne, a jednocześnie daje się, choć nie pozwala zamknąć się w pojęciach. Enigmę można również określić jako fenomen źró-

${ }^{29}$ E. Lévinas, Odkrywając egzystencję z Husserlem i Heideggerem, op. cit., s. 221.

30 A. Jarnuszkiewicz SJ, op. cit., s. 70.

31 Jak pisze Rudolf Otto: „Prawdziwie «tajemniczy» przedmiot jest niepojęty nie tylko dlatego, że moje poznanie jego ma pewne nie dające się usunąć granice, lecz także dlatego, że napotykam tu coś w ogóle "całkiem innego», co z gatunku i istoty jest niewspółmierne do mojej istoty i przed czym cofam się w osłupiającym zdumieniu" (R. Otto, Świętość. Elementy irracjonalne w pojęciu bóstwa $i$ ich stosunek do elementów racjonalnych, tłum. B. Kupis, Warszawa 1999, s. 34). Choć w języku potocznym najczęściej utożsamia się sekret $\mathrm{z}$ tajemnica, to w języku filozoficznym i teologicznym często nabierają one odmiennego znaczenia i należy je rozróżniać. Między innymi Gabriel Marcel wprost pisze o konieczności takiego rozróżnienia, sytuując sekret po stronie posiadania, tajemnicę zaś po stronie tego, czym rozporządzać się nie da (por. G. Marcel, Być i mieć, tłum. P. Lubicz, Warszawa 1986, s. 124). Podstawą dla tych różnic jest również kwestia języka: wypowiadalność sekretu przeciwstawia się tu niewypowiadalności i zasadniczej niepojmowalności tajemnicy jako czegoś całkowicie i nieprzekraczalnie innego. Wypowiedzenie na głos sekretu oznacza wyjawienie go, sprawienie, że przestanie być sekretem, podczas gdy tajemnicy nie da się w pełni wypowiedzieć, opiera sie ona językowi i ludzkiej ingerencji, gdyż jest nietematyzowalna. Można jednak próbować mówić o tajemnicy, wskazywać na jej miejsce wydarzania, a tym samym inicjować w doświadczanie tajemnicy, przy czym żadna z wypowiedzi nie pozbawi jej tajemniczości. 
dłowy (czy Marionowski „fenomen nasycony" 32 transcendencją), inicjujący w żywe doświadczenie rzeczywistości i stojący na straży istotności myślenia, w tym myślenia aksjologicznego. Na próżno jednak nadawać enigmie

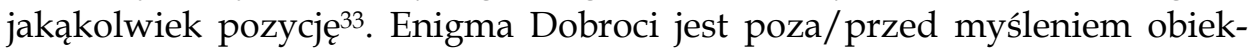
tywistycznym i subiektywistycznym; będąc czymś nieredukowalnym do fenomenu dobra, stanowi ona jego horyzont, jest ethosem (i७७oৎ), z greki „miejscem zamieszkanym”34, czyli źródłem między innymi myślenia aksjologicznego, nie zaś jego pochodną. Dlatego żyć w Dobroci to żyć u siebie, to pamiętać, skąd się pochodzi. Dopóki aksjologia wypływa z Dobroci, dopóty jest zanurzona w ethosie, a to znaczy: nie da się przemienić $\mathrm{w}$ grę, bo w Dobroć grać się nie da, Dobrocią można tylko żyć.

Język Dobroci jest zawsze osobowy. W samym słowie „dobroć” od razu wybrzmiewa ten osobowy charakter: przecież nie powiemy np. o utworze, że jest związany z dobrocią, ani o chlebie, że pachnie dobrocią (chyba że metaforycznie, nawiązując do osoby, która chleb wypiekła). Utwór może być "dobry", jak i chleb może "dobrze" pachnieć, a jednak gdy mowa o osobie, kategoria dobra to jeszcze za mało: za Lévinasem mówię zatem o „dobroci lepszej niż wszystkie dobra, które można [oryg. mógłbym - przyp. M.M.] otrzymać" 35 .

A zatem Enigma Dobroci zakorzeniona jest nie $\mathrm{w}$ bycie $\mathrm{i}$ ontologii, a w metafizyce, myślanej po Lévinasowsku jako etyka, będąca więzią międzyosobową, relacją trzech bliskich sobie osób ${ }^{36}$. Przez enigmatyczny sposób dawania się Dobroci widoczna jest nie tyle jej obiektywność czy subiektywność, co raczej niepojęty aprioryzm ${ }^{37}$, polegający na tym, iż zamiast „posiadać dobra" czy „być dobrzy”, w pierwszej kolejności jesteśmy utkani z Dobroci. Ten aprioryzm Dobroci nazywany jest przez Jarnuszkiewicza "transcendentnym a priori" (transcendentnym wobec podmiotu i przedmiotu) i ujawnia się w metapozycji postaci Trzeciego (i jego Śladu), "oności” rezydującej „poza twarzą" drugiego i zarazem jakby w linii bocznej bezpośredniej bliskości Ja i Drugiego. Ujawnia się zarówno w postaci Trzeciego Absolutnego (Boga osobowego), jak i samej funkcji trzeciego elementu czy

32 Zob. J.-L. Marion, Będąc danym. Esej z fenomenologii donacji, tłum. W. Starzyński, Warszawa 2007, s. 261.

33 "Enigma rozciąga się tak daleko, jak fenomen niosący ślad mowy [dire], która już się wycofała z tego, co powiedziane [dit]"; E. Lévinas, Odkrywając egzystencję z Husserlem i Heideggerem, op. cit., s. 224.

34 Stownik grecko-polski, t. II, red. Z. Abramowiczówna, Warszawa 1960.

${ }^{35}$ E. Lévinas, O Bogu, który nawiedza myśl, op. cit., s. 144.

${ }^{36}$ A. Jarnuszkiewicz SJ, op. cit., s. 69 i 75.

37 Ibidem, s. 75. 
trzeciej postaci (człowieka), która uwalnia z gier opartych na diadyczności myślenia, w tym i z dwubiegunowości aksjologicznej38, jak we wczesnym dzieciństwie ojciec uwalnia matkę i dziecko z "psychotycznej symbiozy". Dwubiegunowość aksjologiczna jest próbą niezaangażowanego opisu (widać tu wpływ fenomenologii Husserla) i za punkt wyjścia bierze neutralność (neutralność reguł gry), nie uwzględniając przy tym zaangażowania uprzedniego (to jest wcześniejszego od wolności wyboru). A zatem w porządku aksjologicznym często nie bierze się pod uwagę atmosfery Dobroci, której zadaniem jest zabezpieczać relację osób przed wzajemnym merkantylnym spoglądaniem na siebie. Atmosfera Dobroci chroni od neutralności i pozornego niezaangażowania, uwalnia z gier i pozycji nieautentycznych, a nawet ideologicznych, $\mathrm{w}$ tym i z "gry w wartości".

Myślenie, w którym zło jest „bratem bliźniakiem dobra" 39 , to myślenie manichejskie, na pierwszy rzut oka zrodzone z lęku o ostateczny wynik: wygraną bądź przegraną dobra. Pierwotnie jednak wypływa ono z lęku o siebie, z niepewności ontologicznej, będącej zapomnieniem o swoim zakorzenieniu i statusie ontycznym, o ethosie człowieka - Enigmie Dobroci. Niepewność ontologiczna, jako niedowierzanie we własne istnienie, czy też, inaczej, lęk hybrydalny (gr. hybris - űßpıs), to brak przytomności siebie jako pełnego i zrodzonego z Dobroci - tego, który nic już nie potrzebuje, by być sobą. Lęk hybrydalny leży często u podstaw tworzenia "gry w wartości", jakby chcąc przez to zrekompensować ów pozorny brak siebie i niepamięć o swoim miejscu zamieszkania - Dobroci. Droga do dojrzałości metafizycznej i etycznej (w sensie Lévinasowym), a dzięki temu aksjologicznej, to droga przebudzenia, droga dojrzewania siebie jako bezpiecznego, będącego u siebie. Ten, kto mieszka w pobliżu Dobroci, nie trzyma się kurczowo "gier w wartości", a liczne hierarchie wartości, często pozornie sobie przeczące, nie doprowadzają go do pomieszania zmysłów i konieczności wyboru jednej z nich lub walki, za wszelką cenę, w jej obronie. Bo i cena może być zbyt wysoka - zapomnienie o osobie i uprzedmiotowienie jej pod płaszczykiem obrony, zawsze w imię jakiegoś "dobra", które okazuje się tak zwanym "mniejszym złem”. Aksjologia zrodzona z Dobroci nie boi się ani istotnie myślanej dekonstrukcji, ani trudnych niekiedy wyborów pomiędzy poszczególnymi wartościami. O wartości bać się nie musimy, gdyż zakorzenione są w Enigmie Dobroci, która jest nietematyzowalna, a przez to niekontrolowalna i niedostępna umysłowi rachującemu, przez co nie podlega

\footnotetext{
38 Ibidem, s. 44.

${ }^{39}$ E. Lévinas, Humanisme de l'autre homme, [cyt. za:] A. Jarnuszkiewicz SJ, op. cit., s. 45.
} 
spaczeniom (a nawet bluźnierstwu). Dlatego też tak rozumianej Dobroci i wypływających $z$ niej wartości nie trzeba bronić: one bronią się same, a nawet więcej - bronią nas ${ }^{40}$ a przede wszystkim zamiast generować lęk, uwalniają zeń.

Reasumując, pod warunkiem, że zdecydujemy się zachować termin „wartość”, Enigmę Dobroci należałoby określić jako wartość myślaną metafizycznie, nie zaś ontologicznie czy aksjologicznie. Dobroć jest niepoddawalna ocenie, gdyż nie ma miary - jest bezmierna. Nie jest przedmiotem akceptacji czy deprecjacji, lecz jedynie afirmacji. Jednak Enigmę Dobroci można również określić jako „przestrzeń życia” 41 , co pozwala z jednej strony na wybrzmienie jej osobowego uwikłania, z drugiej zaś chroni przed interpretacjami Dobroci jako totalizującej i zniewalającej, jako jakiejś abstrakcyjnej normy, idei czy nawet imperatywu kategorycznego.

W ten sposób Lévinas, biorąc na poważnie Heideggerowską dekonstrukcję myślenia według wartości, proponuje myśleć „inaczej niż” wartości, co wpisuje się w jego program myślenia „inaczej niż być” i „inaczej niż wiedzieć", którego zadaniem jest połączenie apofatycznego milczenia z katafatycznym myśleniem (i mówieniem) istotnym. A zatem, z jednej strony unika on języka uprzedmiotawiającego, z drugiej zaś, poprzez liczne metafory i siłowanie się z tradycyjnym językiem filozoficznym, eksplikuje to, co nadaje wartościom istotny sens czy żywotność - samą dobroć Dobroci. Dobroć Dobroci każdego autentycznego dobra.

\section{Goodness That Frees from "Game of Values": On Deconstruction of Axiological Thinking}

Summary

The aim of this article is to show that metaphysical level is the core and condition of possibility of axiology. The paper focuses on methodological differentiation concerning two levels: metaphysical and axiological one. The first one is connected with Goodness, which is the essence of values and an atmosphere that precedes every evaluation, while the second one means discourse about values. When metaphysical level with its Goodness is forgotten, axiology changes itself into "game of values", that arbitrarily builds hierarchy and tries to measure everything. This "game of values" discounts the level of Goodness and functions as a closed area - a system of rules, where there are only

40 A. Jarnuszkiewicz SJ, Inaczej niż myślenie wedtug wartości, czyli od kategorycznej imperatywności i konwencjonalnego dialogu do etyki, „Edukacja Filozoficzna” 1991, nr 11, s. 67.

${ }^{41}$ A. Jarnuszkiewicz SJ, Od systemu do etyki..., op. cit., s. 86. 
pseudo-values (goods), but there is no reference to Goodness. Without taking into consideration the metaphysical (i.e. ethical in Levinasian terminology) level and personal thinking axiology shows itself as a totalitarian construct, which only seems to be interested in Goodness and in fact it is more focused on constructing values. The difference between metaphysics and axiology is described via phenomenological analysis of Enigma of Goodness (the order of metaphysics) and phenomenon of good (the order of axiology). 